\title{
Pelatihan pengolahan hasil pertanian dusun Pulo kalurahan Gulurejo untuk peningkatan ekonomi Kelompok Wanita Tani (KWT) Karya Ibu dimasa pandemi covid-19
}

\author{
Anis Febri Nilansari ${ }^{1, *}$, Setia Wardani ${ }^{2}$, Muncar Tyas Palupi ${ }^{3}$ \\ ${ }^{1}$ Program Sarjana Farmasi, Universitas PGRI Yogyakarta \\ ${ }^{2}$ Program Sarjana Informatika, Universitas PGRI Yogyakarta \\ ${ }^{3}$ Program Sarjana Pendidikan Bahasa dan Sastra Indonesia, Universitas PGRI Yogyakarta \\ Email korespondensi: *anis@upy.ac.id
}

Received June 10, 2021; Revised July 29, 2021; Accepted July 30, 2021

\begin{abstract}
Abstrak
Pandemi Covid-19 sangat berdampak pada hampir semua sektor, demikian pula di sektor UMKM. Usaha Mikro Kecil Menengah umumnya dianggap sebagai penggerak pertumbuhan ekonomi dan pemerataan pembangunan dalam suatu negara berkembang, dimana UMKM mempunyai peranan dalam mengurangi mengurangi pengangguran dan kemiskinan khususnya untuk negara-negara berkembang, sehingga dibutuhkan komitmen dan kemauan yang kuat dalam meningkatkan produktifitas UMKM. UMKM pada Program Kemitraan Masyarakat (PKM) ini adalah Kelompok Tani Wanita (KTW) Karya Ibu yang bergerak pada bidang pertanian hasil bumi, berlokasi di Dusun Pulo Kalurahan Gulurejo. Masalah utama pada mitra adalah melimpahnya hasil pertanian dari KTW yang belum dikelola dan dimanfaatkan oleh masyarakat untuk menambah pendapatan keluarga karena belum adanya pengarahan tentang pengolahan makanan ringan berbahan pisang dan singkong, jangkauan pasar yang masih lokal, desain produk yang masih konvensional. Tujuan pengabdian adalah membentuk dan mengembangkan kelompok usaha di Dusun Pulo yang mandiri secara ekonomi dengan memberikan solusi atas masalah pada mitra. Solusi untuk mengatasi masalah pada mitra antara lain pelatihan pengolahan hasil pertanian (berupa makanan ringan) dan pelatihan bahasa promosi serta pembuatan desain produk dengan memanfaatkan Teknologi Informasi dan Komunikasi. Hasil dari PkM ini adalah makanan ringan dari pisang dan singkong yang memiliki nilai jual tinggi serta promosi produk dengan memanfaatkan media sosial.
\end{abstract}

Kata Kunci: KWT Karya Ibu; pisang; singkong; diversifikasi

\begin{abstract}
The Covid-19 pandemic had an impact on almost all sectors, as well as the UMKM sector. The UMKM are generally considered to be the drivers of economic growth and equitable development in a developing country, where UMKM s have a role in reducing unemployment and poverty, so a strong commitment and will is needed in increasing the productivity of UMKM. UMKM in the Community Partnership Program (PKM) are the Women Farmers Group (KTW) Karya Ibu which is engaged in agricultural products, located in Pulo Kalurahan Gulurejo Hamlet. The main problem for partners is the abundance of agricultural products from $K T W$ that have not been managed and utilized by the community to increase family income because there is no guidance on processing snacks made from bananas and cassava, market reach is still local, product design is still conventional. The purpose of the service is to form and develop a business group in Pulo Hamlet that is economically independent by providing solutions to problems for partners. Solutions to overcome problems with partners include training on processing agricultural products (in the form of snacks) and training on product design making by utilizing Information and Communication Technology. The results of this PkM are snacks made from bananas and cassava which have a high selling value as well as product promotion by utilizing social media.
\end{abstract}

Keywords : KWT Karya Ibu; banana; cassava; diversification

\section{PENDAHULUAN}

Desa Pulo secara geografis masuk dalam Kalurahan Galurejo, Kabupaten Kulon Progo. Jarak Desa Pulo ke Universitas PGRI Yogyakarta adalah 28,7 Km. Luas wilayah Pedukuhan Pulo yaitu $658.627 \mathrm{~m}^{2}$ Jumlah penduduk di Dusun Pulo sebanyak 836 jiwa, terdiri dari 416 laki-laki dan 420 perempuan, rata-rata penduduk 
laki-laki bermata pencaharian sebagai petani dan buruh pasir di Sungai Progo, sedangkan untuk perempuan sebagai ibu rumah tangga.

Hasil bumi yang merupakan ciri khas dari Duson Pulo yaitu singkong dan pisang. Pada Tahun 2017 Kepala Dusun Pulo membentuk Kelompok Wanita Tani (KWT) Karya Ibu untuk mengelola usaha pertanian masyarakat yaitu singkong dan pisang untuk meningkatkan pendapatan masyarakat di Dusun Pulo. Berbagai pelatihan dan pendampingan mulai dari cara tanam, perawatan dan pemberian pupuk dilakukan oleh Dinas Pertanian Kabupaten Kulon Progo kepada petani singkong dan pisang di Duson Pulo. Pelatihan dan pendampingan tersebut merupakan upaya yang ditujukan untuk meningkatkan kesejahteraan masyarakat kearah yang lebih baik dan merata, sehingga dapat meningkatkan taraf hidup dan kualitas hidup masyarakat [1] Namun sering berjalannya waktu, KWT Karya Ibu mendapatkan berbagai masalah diantaranya adalah melimpahnya hasil panen masyarakat namun nilai jual yang tidak sebanding dengan waktu dan biaya perawatan bibit tanaman sampai dengan menghasilkan buah untuk dijual. Selain itu animo masyarakat lokal untuk mengkonsumsi hasil pertanian pada KWT Karya Ibu sangat rendah. Hal ini juga terjadi pada masa pendemi covid-19, bahwa terjadi penurunan perilaku konsumtif masyarakat [2].

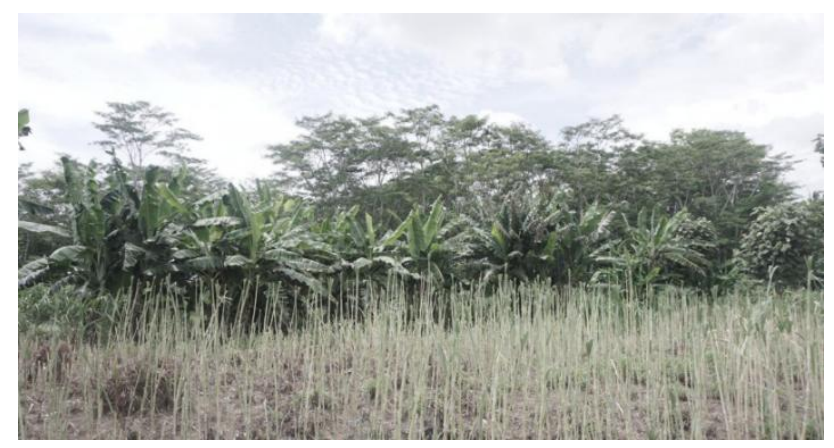

Gambar 1. Tanaman Pisang Dusun Pulo

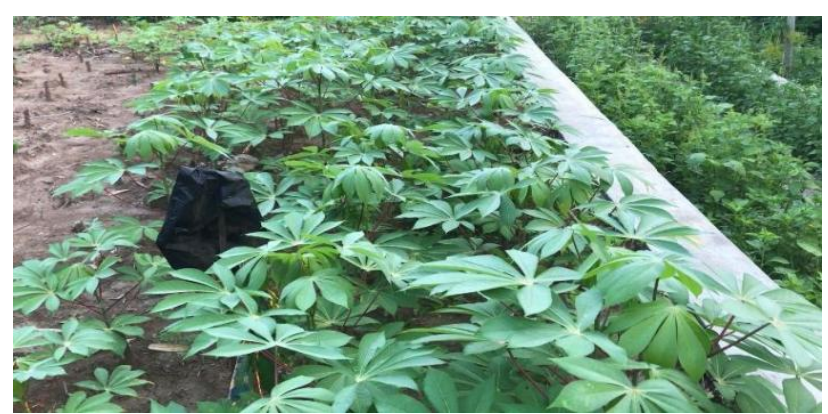

Gambar 2. Tanaman Singkong Dusun Pulo

Saat ini pemanfaatan hasil bumi Dusun Pulo berupa pisang dan singkong yang sudah matang hanya dimanfaatkan sebagai hasil panen yang siap jual dan belum dilakukan pengolahan lebih lanjut menjadi produk makanan. Apabila pada saat musim panen singkong dan pisang tiba, bahkan hasil panen hanya digunakan sebagai pakan ternak oleh karena melimpahnya hasil panen yang tidak sebanding dengan konsumen atau pembeli singkong dan pisang. Pemanfaatan potensi hasil pertanian pada Dusun Pulo merupakan masalah utama pada KWT Karya Ibu. Sementara itu, sektor pertanian masih menjadi andalan penciptaan lapangan pekerjaan dalam jumlah yang cukup besar dibandingkan dengan sektor-sektor lainnya dalam perekonomian di Indonesia. Hal ini menjadikan peluang sektor pertanian dalam pengaruhnya terhadap perekonomian di Indonesia [3]. Sehingga berdasarkan latar belakang tersebut dan berdasarkan diskusi dari perangkat desa yaitu kepala desa dibutuhkan usaha pemberdayaan masyarakat berupa pemanfaatan hasil bumi berupa singkong dan pisang menjadi produk olahan yang dapat dijual dan memiliki nilai jual tinggi sehingga dapat mendukung perekonomian KWT Karya Ibu Dusun Pulo.

Pemanfaatan hasil bumi Duson Pulo membutuhkan kesadaran warga untuk memanfaatkan singkong dan pisang menjadi produk olahan yang dapat memiliki nilai jual, sehingga pada kegiatan Pengabdian Kepada Mayarakat ini dimulai dengan melakukan penyuluhan sebagai upaya penguatan sumber daya masyarakat, kemudian dilanjutkan pelatihan pengolahan singkong dan pisang menjadi olahan produk yang bernilai jual 
tinggi dan kemudian diteruskan dengan pembuatan media promosi dengan memanfaatkan teknologi informasi dengan menggunakan bahasa promosi yang tepat dan menarik.

\section{METODE}

Metode yang digunakan pada pengabdian masyarakat ini adalah 25\% untuk ceramah, 50\% untuk praktek, dan $25 \%$ untuk tanya jawab. Pelaksaan pengabdian masyarakat dilaksanakan secara luring dan daring dengan menggunakan media zoom meeting. Pemanfaatan platform digital di masa pandemi covid-19 dilakukan untuk mengurangi kontak fisik dan meminimalisir adanya kerumunan [4]. Pelaksanaan pengabdian secara daring dilaksanakan dengan memberikan materi berupa ceramah terkait dengan pemanfaatan hasil pertanian untuk peningkatan ekonomi masyarakat Dusun Pulo Kalurahan Gulurejo. Pemberian ceramah dilakukan sebagai bagian dari kegiatan penguatan Sumber Daya Manusia (SDM) anggota KWT Karya Ibu agar semangat dalam memanfaatkan hasil bumi sebagai bagian dari peningkatan ekonomi di masa pandemi covid-19.

Metode ceramah juga diberikan dengan memberikan materi berupa cara promosi produk dengan memanfaatkan media sosial dan bahasa promosi yang baik dan menarik. Ceramah disampaikan dengan memberikan materi slide berupa power point untuk mempermudah peserta dalam memahami setiap materi yang diberikan.

Pelaksaan pengabdian masyarakat dengan metode praktek dilakukan untuk memberikan pelatihan secara langsung kepada anggota KWT Karya Ibu terkait cara pengolahan singkong dan pisang menjadi produk kue yang memiliki nilai jual tinggi. Pelaksaan pelatihan dilaksanakan di rumah ketua Dusun Pulo dan dilaksanakan dengan jaga jarak dengan protokol kesehatan yang ketat guna mengindari penyebaran covid-19. Untuk lebih rincinya lihat pada tabel 1 dibawah ini.

Tabel 1. Kegiatan dan Langkah yang dilakukan

No Kegiatan

1 Perijinan ke Padukuhan Pulo

2 Koordinasi mitra terkait kegiatan Pengabdian kepada Masyarakat

$3 \quad$ Koordinasi pelaksanaan ceramah secara daring

$4 \quad$ Penyuluhan manfaat pisang dan singkong Dilaksanakan pada hari senin tanggal 05 April 2021

5 Penyuluhan dan pelatihan promosi melalui sosial media dan pengemasan produk yang menarik Dilaksanakan pada hari selasa tanggal 06 April 2021

Ceramah a. Pembuatan permohonan surat ijin ke LPPM untuk kegiatan Pengabdian kepada Masyarakat.

b. Perijinan pada Padukuhan Pulo

a. Menentuan lokasi kegiatan PPM

b. Menentukan waktu dan tanggal pelaksanaan PPM

a. Menentukan waktu dan tanggal pelaksanaan ceramah

b. Pelaksanaan ceramah dengan memanfaatkan media zoom meeting

a. Penyuluhan manfaat pisang dan singkong bagi kesehatan

b. Penyuluhan manfaat pisang dan singkong sebagai produk yang bernilai jual tinggi

a. Pelatihan promosi melalui sosial media

b. Pelatihan dan praktik pengemasan produk

c. Pelatihan pembuatan desain produk

d. Pelatihan penggunaan bahasa pada promosi produk

Pelatihan

$1 \quad$ Koordinasi pelaksanaan pelatihan secara luring

a. Menentukan waktu dan tanggal
pelaksanaan pelatihan

b. Melaksanakan pelatihan dengan menerapkan protokol kesehatan mengindari kerumunan

2 Pelatihan pengolahan singkong dan pisang a. Pelatihan pengolahan singkong dan pisang menjadi kue yang bernilai jual tinggi Dilaksanakan pada hari jumat tanggal 09 April 2021

b. Pelatihan pemilihan bahan baku dari produk

c. Pelatihan pemberian harga jual untuk produk

d. Pendampingan dan evaluasi 


\section{HASIL DAN PEMBAHASAN}

Kegiatan Pelatihan Pemanfaatan Sumber Daya Alam, Promosi Berbasis TI dan Bahasa Promosi Bagi Kelompok Wanita Tani (KWT) Karya Ibu Dusun Pulo Kalurahan Gulurejo Untuk Peningkatan Ekonomi Masyarakat Dimasa Pandemi Covid-19 berlangsung secara daring dan luring. Pelaksanaan Pengabdian Kepada Masyarakat dilaksanakan dengan 2 cara yaitu metode daring dan luring olehkarena kegiatan ini berlangsung pada saat masa pandemi covid-19. Metode daring dilakukan pemberian materi berupa ceramah atau penyuluhan, sedangkan metode luring dilakukan untuk memberikan praktek secara langsung cara pemanfaatan sumber daya alam yang ada di Dusun Pulo yaitu pisang dan singkong menjadi kue yang memiliki nilai jual tinggi. Praktek secara langsung dilakukan untuk melaksakan tugas dan tanggungjawab dosen yaitu Tri Dharma Perguruan Tinggi berupa Pendidikan, Penelitian dan Pengabdian, oleh karena itu pengabdian tetap dijalankan. Pengabdian Kepada Masyarakat secara luring ini berlangsung dengan menerapakan protokol kesehatan berupa wajib memakai masker, cuci tangan sebelum mengikuti penyuluhan dan pengolahan, jaga jarak dan menghindari kontak fisik.

Sebelum dilakukan pengabdian kepada masyarakat, dilakukan analisis situasi kondisi mitra dengan melakukan wawancara terhadap Ketua Dukuh Pulo dengan menggunakan analisis SWOT. Penggunaan analisis SWOT dapat memberikan solusi dari masalah yang ada pada suatu UMKM dengan menidentifikasi 4 faktor yaitu strenght, weakness, opportunity, dan threat [5]. Hasil wawancara berupa analisis SWOT dapat membantu penentuan jalannya pengabdian kepada masyarakat yang dapat dilihat pada tabel 2.

Tabel 2. Analisis SWOT KWT Karya Ibu Dusun Pulo Kalurahan Gulurejo

\begin{tabular}{|c|c|c|}
\hline & Strength $(S)$ & Weakness $(S)$ \\
\hline $\begin{array}{c}\text { Faktor- faktor } \\
\text { Internal }\end{array}$ & $\begin{array}{l}\text { - Kelompok usaha KWT } \\
\text { Karya Ibu di Dusun Pulo } \\
\text { memiliki bahan utama } \\
\text { berupa singkong dan } \\
\text { pisang yang siap untuk } \\
\text { diolah. } \\
\text { Singkong dan pisang } \\
\text { sebagai hasil pertanian } \\
\text { khas di Dusun Pulo. }\end{array}$ & $\begin{array}{l}\text { Kurangnya kesadaran } \\
\text { anggota KWT Karya Ibu di } \\
\text { Dusun Pulo dalam } \\
\text { memanfaatkan singkong } \\
\text { dan pisang menjadi produk } \\
\text { olahan. } \\
\text { Keterbatasan keterampilan } \\
\text { untuk mengolah singkong } \\
\text { dan pisang menjadi produk } \\
\text { olahan yang bernilai jual } \\
\text { tinggi }\end{array}$ \\
\hline Opportunity $(O)$ & Stratesi SO & Strategi \\
\hline 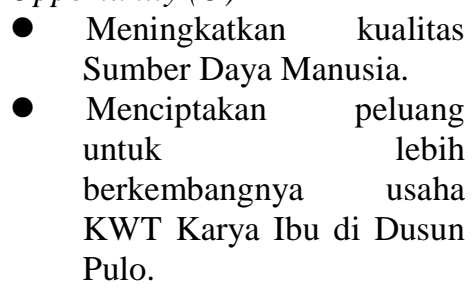 & $\begin{array}{l}\text { Menambah jenis usaha lainnya } \\
\text { di kelompok usaha KWT Karya } \\
\text { Ibu di Dusun Pulo dengan } \\
\text { memanfaatkan hasil pertanian } \\
\text { khas di Dusun Pulo. }\end{array}$ & $\begin{array}{l}\text { Penyuluhan dan pelatihan } \\
\text { pemanfaatan singkong dan } \\
\text { pisang menjadi produk olahan } \\
\text { kue yang bernilai jual tinggi. }\end{array}$ \\
\hline $\begin{array}{l}\text { Threat }(T) \\
\text { - Persaingan pasar dengan } \\
\text { produk olahan sejenis. } \\
\text { - Pemasaran yang masih } \\
\text { lokal. }\end{array}$ & $\begin{array}{l}\text { Strategi ST } \\
\text { Membuat kue berbahan dasar } \\
\text { singkong dan pisang dengan } \\
\text { dengan berbagai jenis dan } \\
\text { disertai dengan promosi kue } \\
\text { sehat dan bergizi. }\end{array}$ & $\begin{array}{l}\text { Strategi WT } \\
\text { Pendampingan pembuatan } \\
\text { kemasan produk yang menarik } \\
\text { disertai dengan pembuatan } \\
\text { website sebagai media promosi } \\
\text { online. }\end{array}$ \\
\hline
\end{tabular}

Berdasarkan analisis SWOT, dilakukan pemilihan metode pelaksanaan PKM di Dusun Pulo Kalurahan Gulurejo yaitu dengan cara penyuluhan, pelatihan dan pendampingan pengolahan pemanfaatan hasil sumber daya alam berupa singkong dan pisang. Pelatihan disertai dengan manajemen pemasaran produk dengan memanfaatkan TIK serta menggunaan bahasa promosi yang menarik. Penerapan penyuluhan diawali dengan menentukan sarana dan prasarana yang diperlukan dalam melakukan diversifikasi dari produk KWT yaitu berupa singkong dan pisang, dilanjutkan dengan cara pengolahan dan pengemasan menjadi kue yang memiliki nilai ekonomis tinggi. Pelatihan terkait bahasa promosi diberikan, karena pembuatan kata-kata promosi yang tepat akan berdampak pada berhasil atau tidaknya dalam penjualan produk. Pelatihan pemanfaatan TIK diberikan dengan maksud agar jangkauan pemasaran dapat dilakukan secara luas sehingga produk dapat 
dikomersialisasikan secara lokal dan konvensional namun juga melalui media sosial [6]. Peserta PkM adalah anggota KWT di Dusun Pulo Kelurahan Gulurejo, yang bertujuan memberikan keterampilan kepada anggota KWT tidak hanya bergerak dalam bidang pertanian, namun juga memanfaatkan singkong dan pisang menjadi produk kue yang memiliki nilai jual tinggi.

\subsection{Penyuluhan Manfaat Singkong dan Pisang}

Pada hari pertama Pengabdian Kepada Masyarakat di Dusun Pulo Kelurahan Gulurejo ini dilaksanakan pada tanggal 05 April 2021 pukul 09.00-10.30 WIB. Dilakukan penyampaian 2 materi berupa manfaat singkong dan pisang bagi kesehatan dan manfaat singkong dan pisang sebagai produk olahan yang dapat bernilai jual tinggi.

Penyampaian materi dimulai dengan pemanfaatan singkong dan pisang. Singkong dan pisang memiliki beragam manfaat bagi kesehatan apabila dilihat dari kandungan gizinya. Pisang (Musa paradisiaca) merupakan buah yang mengandung sumber karbohidrat, mineral serta vitamin B6 dan vitamin $\mathrm{C}$ yang tinggi [7]. Kandungan karbohidrat sederhana dan kompleks yang ada pada pisang dapat bermanfaat sebagai sumber energi bagi tubuh. Hasil pertanian yang lain yaitu singkong (Manihot esculenta) merupakan sumber bahan makanan ketiga di Indonesia setelah padi dan jagung. Singkong banyak mengandung karbohidrat, protein, lemak, kalsium, fosfor, dan zat besi. Selain itu dalam singkong juga terkandung vitamin B1 dan vitamin C [8][9]. Sementara itu singkong dan pisang, di Dusun Pulo Kalurahan Gulurejo hanya dimanfaatkan dengan dijual perkilo dengan nilai jual yang rendah, bahkan saat musim panen singkong dan pisang tiba, bahkan hasil panen hanya digunakan sebagai pakan ternak oleh karena melimpahnya hasil panen yang tidak sebanding dengan konsumen atau pembeli singkong dan pisang.

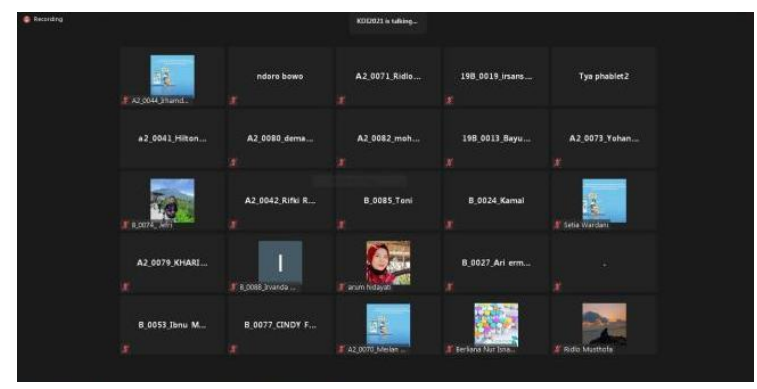

Gambar 3. Penyampaian materi manfaat singkong dan pisang

Pemanfaatan singkong dan pisang belum sepenuhnya dilakukan oleh masyarakat KWT Karya Ibu Dusun Pulo. Singkong dan pisang belum banyak dimanfaatkan menjadi produk olahan, sehingga pada materi kedua dilakukan ceramah terkait manfaat hasil pertanian menjadi produk olahan yang memiliki nilai jual tinggi. Pemanfaatan sumber daya alam sudah seharusnya dapat meningkatkan taraf perekonomian bagi para petani untuk memenuhi kebutuhan hidupnya sehari-hari. Pengelolaan hasil pertanian yang tepat tentunya akan menambah nilai jual dari hasil pertanian itu sendiri [10]. Gambar 3. merupakan penyampaian materi pemanfaatan singkong dan pisang yang disampaikan pemateri kepada KWT Karya Ibu Dusun Pulo Kalurahan Gulurejo.

Materi penyuluhan manfaat singkong dan pisang dilakukan secara daring dengan bantuan media zoom meeting. Materi yang disampaikan berupa power point. Penyampaian materi disertai dengan diskusi tanya jawab terkait manfaat singkong dan pisang dari segi kesehatan serta materi pemanfaatan singkong dan pisang untuk peningkatan nilai jual.

\subsection{Penyuluhan Promosi dan Pengemasan Produk}

Pada hari kedua Pengabdian Kepada Masyarakat di Dusun Pulo Kalurahan Gulurejo ini dilaksanakan pada tanggal 06 April Juni 2021 pukul 09.00-11.00 WIB. Dilaksanakan pemberian materi tentang promosi dan pengemasan produk. Materi ini merupakan kelanjutan dari materi yang pertama yaitu tentang manfaat singkong dan pisang bagi kesehatan dan pemanfaatan singkong dan pisang menjadi produk olahan yang bernilai jual tinggi.

Penyuluhan tentang promosi dan pengemasan produk dilakukan secara daring dengan media zoom meeting yang dihadiri oleh 22 warga KWT Karya Ibu Dusun Pulo Kalurahan Gulurejo. Pemilihan materi berupa promosi dimaksudkan agar KWT Karya Ibu Dusun Pulo Kalurahan Gulurejo dapat memanfaatkan media sosial sebagai sarana dalam memperkenalkan produknya agar dapat dikenal masyarakat luas. Menurut data survei Kominfo pada tahun 2017 menunjukkan bahwa lebih dari setengah masyarakat Indonesia 
menggunakan telepon pintar atau smartphone dalam keidupan sehari-hari yaitu sebesar 66,3\% dan akan terus mengalami peningkatan setiap tahunnya. Rata-rata mereka menggunakan smartphone 3-5 jam perhari dalam aktivitasnya. Orang yang mengunakan smartphone tidak hanya usia dewasa, namun 50,79\% populasi usia 5065 tahun juga menggunakan smartphone[11]. Hal inilah yang melatar belakangi agar masyarakat dituntut dapat menggunakan teknologi untuk diambil manfaatnya yaitu salah satunya sebagai media dalam mempromosikan produk yang dijual.

Penyampaian materi tentang promosi diawali dengan manfaat sosial media dalam kehidupan sehari-hari, dilanjutkan dengan macam-macam media sosial yang dapat dimanfaatkan dalam promosi produk yang dihasilkan KWT Karya Ibu. Pada pertemuan ke dua pengabdian masyarakat ini, dibuat media sosial yang dapat digunakan KWT Karya Ibu Dusun Pulo Kalurahan Gulurejo dalam promosi produk yaitu dengan menggunakan Whatsapp, instagram dan website.

Setelah dilakukan penyampaian materi berupa promosi dengan media online, selanjutnya dilakukan penyampaian materi tentang pengemasan produk. Kemasan yang menarik akan menjadi daya tarik tersendiri bagi konsumen yang ingin membeli produk. Materi pengemasan produk dilakukan untuk memberikan gambaran kepada KWT Kaya Ibu Dusun Pulo Kalurahan Gulurejo dalam mengemas produk yang dapat menjadikan produk bernilai jual tinggi. Dalam kesempatan ini, pemateri memberikan contoh terkait produk kue dengan bahan dasar singkong dan pisang yang sudah dikemas secara menarik. Gambar 4. merupakan contoh produk olahan singkong dan pisang yang sudah dikemas dan dapat bernilai jual tinggi.

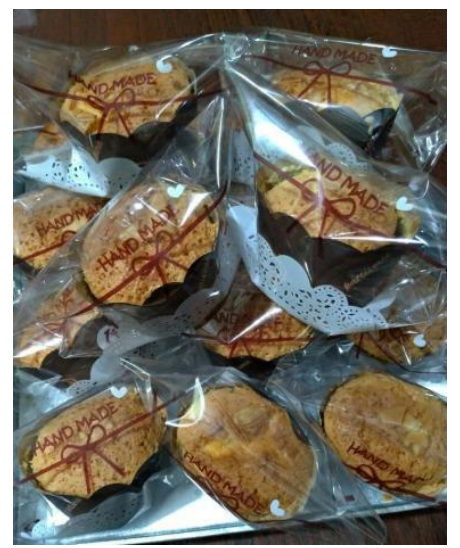

Gambar 4. Produk kue dengan pengemasan menarik

\subsection{Pelatihan Pembuatan Produk Olahan Berbahan Dasar Singkong dan Pisang}

Hari ketiga pelaksanaan Pengabdian Kepada Masyarakat dilakukan pelatihan pembuatan kue berbahan dasar singkong dan pisang. Pelatihan ini dilaksanakan di Rumah Kepala Dukuh Pulo dengan dihadiri 18 peserta dari KWT Karya Ibu Dukuh Pulo Kalurahan Gulurejo. Pelatihan dilaksanakan dengan jaga jarak dan menerapkan protokol kesehatan untuk mencegah penyebaran covid-19. Sebelum pelatihan dilaksanakan, dipersiapkan terlebih dahulu alat dan bahan yang dibutuhkan. Alat yang dibutuhkan diantaranya ialah oven, kompor, baskom, piring, sendok, kocokan kue. Sedangkan bahan yang dibutuhkan ialah singkong, pisang, tepung terigu, minyak, soda kue, dan gula.

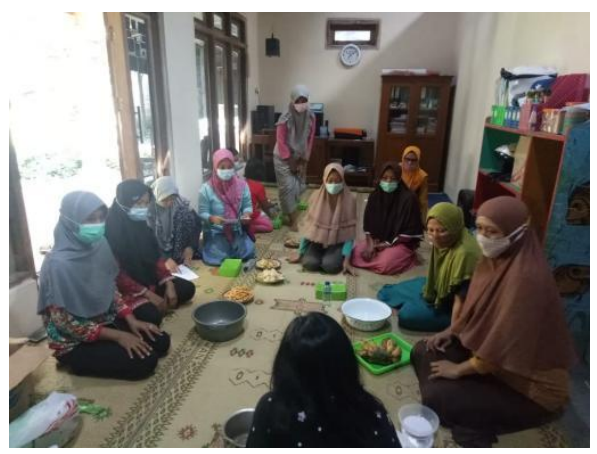

Gambar 5. Pelatihan Pembuatan Kue 
Pada pelatihan yang sudah berlangsung tersebut, terlihat bahwa peserta antusias untuk mengikuti pelatihan dengan ditandai bahwa peserta aktif ikut serta dalam pembuatan kue berbahan dasar singkong dan pisang. Gambar 5. merupakan proses pembuatan produk olahan dari singkong dan pisang yang dilakukan ibuibu KWT Karya Ibu Dusun Pulo Kalurahan Gulurejo.

Kue berbahan dasar singkong dan pisang yang sudah jadi selanjutnya dilakukan pengemasan dan dilanjutkan penyampaian materi tentang strategi penentuan harga produk. Singkong dan pisang yang sudah diolah menjadi kue akan mengalami kenaikan harga dan berpotensi untuk dijual agar meningkatkan pendapatan bagi anggota KWT Karya Ibu Dusun Pulo Kalurahan Gulurejo. Selain penentuan harga produk, diberikan juga bagaimana menggunakan bahasa promosi dalam penjualan produk yang nantinya akan dipasarkan secara online. Dipaparkan contoh-contoh bahasa promosi yang menarik dari berbagai kalimat promosi yang sudah ada di media massa agar bisa menjadi inspirasi bagi penjualan produk kue ini. Keunikan dalam iklan adalah penggunaan bahasa yang digunakan di dalamnya agar pesan yang disampaikan sesuai dengan target audience [12].

Akhir kegiatan pengabdian masyarakat ini, pengabdi melakukan evaluasi dengan cara mengukur antusiasme peserta dalam memanfaatkan hasil pertanian menjadi produk yang bernilai jual tinggi. Evaluasi dilakukan dengan cara pembagian kuesioner dengan mengirim link google form di grup Whatss App KWT Karya Ibu Dusun Pulo Kalurahan Gulurejo. Hasil kuesioner dapat dilihat pada tabel 3.

Tabel 3. Kuesioner Antusiasme Peserta Dalam Pengolahan Hasil Pertanian

\begin{tabular}{clccc}
\hline No & \multicolumn{1}{c}{ Variabel } & Ya & Tidak \\
\hline 1 & $\begin{array}{l}\text { Pemanfaatan hasil pertanian menjadi produk olahan } \\
\text { merupakan ide yang bagus }\end{array}$ & 19 & 1 \\
2 & $\begin{array}{l}\text { Saya berminat untuk mengolah singkong dan pisang } \\
\text { menjadi kue }\end{array}$ & 16 & 4 \\
3 & $\begin{array}{l}\text { Saya berminat untuk menjual hasil produk olahan } \\
\text { Pelatihan pembuatan kue berbahan dasar singkong dan } \\
\text { pisang mudah dipraktekkan }\end{array}$ & 9 & 11 \\
5 & $\begin{array}{l}\text { Pelatihan bahasa promosi dan penggunaan media sosial } \\
\text { sebagai promosi produk mudah dipahami }\end{array}$ & 13 & 7 \\
\hline
\end{tabular}

Dari total 25 anggota KWT Karya Ibu Dusun Pulo Kalurahan Gulurejo, terhitung 20 orang mengisi kuesioner secara lengkap. Hasil kuesioner secara keseluruhan menunjukkan bahwa sebagian besar peserta berminat untuk mengolah hasil pertanian yaitu singkong dan pisang menjadi produk olahan kue, namun hanya $50 \%$ dari peserta yang berminat untuk mengkomersialisasikan produk tersebut. Berdasarkan kesan dan saran yang diisi oleh peserta, perlu adanya pengabdian masyarakat lebih lanjut terkait promosi dengan menggunakan website serta perlu dilakukan pendampingan pengurusan izin pangan produksi rumah tangga.

\section{KESIMPULAN}

Dusun Pulo Kalurahan Gulurejo memiliki hasil pertanian khas yaitu singkong dan pisang. Hasil pertanian tersebut dimanfaatkan para petani dengan cara dijual perkilo, namun apabila pada saat masa panen tiba, hasil panen hanya digunakan sebagai pakan ternak oleh karena melimpahnya hasil panen yang tidak sebanding dengan konsumen atau pembeli singkong dan pisang. Dari Permasalahan tersebut, pelaksanaan PkM di Dusun Pulo Kalurahan Gulurejo yaitu dengan mengadakan penyuluhan, pelatihan dan pendampingan pengolahan Sumber Daya Alam (SDA) lokal berupa hasil produksi (singkong dan pisang) menjadi olahan yang bernilai ekonomis tinggi disertai dengan manajemen pemasaran produk dengan pemanfaatan sosial media dan bahasa promosi. Singkong dan pisang yang sebelumnya mempunyai nilai ekonomis rendah dengan kegiatan PkM ini dapat diubah menjadi produk bernilai ekonomis tinggi yaitu berupa kue berbahan dasar singkong dan pisang.

\section{DAFTAR PUSTAKA}

[1] S. Tinggi, I. Ekonomi, and M. Tolitoli, "Peranan Sektor Pertanian Dalam Perencanaan," vol. 1, no. 2, 2020.

[2] P. Muhammad and A. Mannan, Pemikiran muhammad abdul mannan tentang konsumsi dan relevansinya terhadap pandemi covid-19 skripsi. 2021.

[3] R. F. Widyawati, “Analisis Keterkaitan Sektor Pertanian Dan Pengaruhnya Terhadap Perekonomian In donesia (Analisis Input Ouput),” Jurnal Economia, vol. 13, no. 1, p. 14, Apr. 2017.

[4] M. Hasbi and W. Sumarni, "Pemanfaatan Platform Digital di Masa Pandemi Covid-19," 2020.

[5] I. Andriyanto, “Analisis SWOT dalam Pengembangan Bisnis ( Studi pada Sentra Jenang di Desa Wisata 
Kaliputu Kudus )," vol. 5, no. 2, pp. 363-382.

[6] A. F. Nilansari and S. Wardani, "Pelatihan Pengolahan Kulit Melinjo Sebagai Camilan Sehat Untuk Peningkatan Pendapatan Kwt Sejahtera Dusun Kepuh Kulon Desa Wirokerten," KACANEGARA J. Pengabdi. pada Masy., vol. 4, no. 1, p. 37, 2021.

[7] D. I. Gizi, F. Kedokteran, and U. Diponegoro, “Journal of Nutrition College," vol. 7, pp. 8-14, 2018.

[8] D. Cristiana et al., "Kontribusi Pemanfaatan Ubi Jalar Sebagai Produk Lokal Desa Sayang, Kabupaten Sumedang Terhadap Peningkatan Ekonomi Kreatif Masyarakat Setempat," 2018.

[9] W. Tuhenay, "Jurnal Mitra Pendidikan ( JMP Online )," vol. 2, no. 2, pp. 191-204, 2018.

[10] A. Heryawan, A. Fauzi, and A. Hidayat, "Analisis Ekonomi Dan Kebijakan Sumber Daya Alam Provinsi Jawa Barat," J. Agric. Resour. Environ. Econ., vol. 1, no. 2, pp. 1-11, 2016.

[11] Kominfo, "Survey Penggunaan TIK serta Implikasinya terhadap Aspek Sosial Budaya Masyarakat," 2017.

[12] M. Umiyati and I. G. A. A. D. Susanthi, "Pemanfaatan Bahasa Iklan sebagai Penunjang Media Promosi di Jalan Akasia," Linguist. Community Serv. J., vol. 1, no. 2, 2021. 